\title{
Kerentanan Jenis Tepung terhadap Infestasi Kumbang Tepung Merah (Tribolium castaneum Herbst) (Coleoptera: Tenebrionidae)
}

\author{
Hendrival ${ }^{*}$, Latifah, Dedi Saputra dan Orina \\ Program Studi Agroekoteknologi, Fakultas Pertanian, Universitas Malikussaleh \\ Jalan Banda Aceh-Medan, Kampus Reuleut Muara Batu, Aceh Utara \\ *Alamat korespondensi: hendrival@unimal.ac.id
}

\begin{abstract}
Susceptibility of various flour types to the investation of red flour beetle (Tribolium castaneum Herbst) (Coleoptera: Tenebrionidae)
\end{abstract}

The research on the level of flour susceptibility against infestation of Tribolium castaneum has been conducted in laboratory under conditions of $28-30^{\circ} \mathrm{C}$ and relative humidity of $70-75 \%$. Each type of flour was infested by 10 pairs of $T$. castaneum adult. Variables observation included the population growth, development period, weight losses percentage and susceptibility index. The results showed that degree of flour suitability against population growth namely wheat flour $>$ corn flour $>$ bran $>$ mungbean flour $>$ rice flour $>$ potato flour $>$ purple cultivar sweet potato flour $>$ bread crumbs $>$ glutinous rice flour $>$ tapioca flour $=$ sago flour. The longest median development time of $T$. castaneum was found in tapioca and sago flours of 86 days while the shortest was in wheat flour of 23.33 days. The highest weight loss percentage occurred on wheat and corn flours. The susceptibility level of flours to $T$. castaneum with resistant category included tapioca flour, corn flour, glutinous rice flour, purple cultivar sweet potato flour and bread crumbs. Mungbean flour was in moderate gategory while potato flour was in resistant to moderate category. Rice flour and bran were classified in susceptible category while corn and wheat flours were classified as highly susceptible.

Keywords: Tribolium castaneum, Flour, Population growth, Development period, Susceptibility

\begin{abstract}
ABSTRAK
Penelitian tingkat kerentanan jenis tepung terhadap infestasi Tribolium castaneum telah dilakukan di laboratorium pada kondisi suhu $28-30^{\circ} \mathrm{C}$ dan $\mathrm{RH} 70-75 \%$. Setiap jenis tepung diinfestasi 10 pasang imago $T$. castaneum. Variabel pengamatan meliputi pertumbuhan populasi, periode perkembangan, persentase susut berat dan indek kerentanan. Hasil penelitian menunjukkan bahwa tingkat kesesuaian jenis tepung terhadap pertumbuhan populasi yaitu tepung gandum $>$ tepung jagung $>$ dedak $>$ tepung kacang hijau $>$ tepung beras $>$ tepung kentang $>$ tepung ubi jalar kultivar ungu $>$ tepung panir $>$ tepung ketan putih $>$ tepung tapioka $=$ tepung sagu. Median waktu perkembangan T. castaneum paling lama dijumpai pada tepung tapioka dan sagu yaitu 86 hari, sedangkan paling singkat pada tepung gandum yaitu 23,33 hari. Susut berat tepung paling banyak terjadi pada tepung gandum dan jagung. Tingkat kerentanan jenis tepung terhadap T. castaneum yaitu katagori resisten meliputi tepung tapioka, tepung sagu, tepung ketan putih, tepung ubi jalar kultivar ungu, dan tepung panir. Katagori moderat yaitu tepung kacang hijau, sedangkan tepung kentang tergolong resisten sampai moderat. Tepung beras dan dedak tergolong katagori rentan, sedangkan tepung jagung dan gandum tergolong katagori sangat rentan.
\end{abstract}

Kata Kunci: Tribolium castaneum, Tepung, Pertumbuhan populasi, Periode perkembangan, Tingkat kerentanan 


\section{PENDAHULUAN}

Kumbang tepung merah, Tribolium castaneum (Herbst) (Coleoptera: Tenebrionidae) merupakan hama polifag dan kosmopolitan yang merusak produk pertanian di penyimpanan (Weston \& Rattlingourd, 2000; Sarwar, 2015). Hama ini juga dikenal sebagai hama utama di tempat pengolahan produk pertanian serta industri biskuit (Mewis \& Ulrichs, 2001; Odeyemi et al., 2005; Verheggen et al., 2007). T. castaneum digolongkan sebagai hama sekunder pada komoditas beras dan serealia lain karena menyerang komoditas yang telah rusak akibat serangan hama primer maupun kerusakan akibat penanganan pascapanen yang kurang tepat. $T$. castaneum dapat hidup pada jenis makanan seperti tepung di penyimpanan dan fasilitas pengolahan makanan serta pabrik tepung dan makanan ternak seperti dedak (Campbell \& Runnion, 2003). T. castaneum memiliki tingkat preferensi yang signifikan pada berbagai jenis tepung sehingga menentukan tingkat kerentanan terhadap produk pertanian yang disimpan (Kheradpir, 2014). Campbell \& Runnion (2003) menyebutkan bahwa jenis tepung yang berbeda mengandung nutrisi yang berbeda dan dapat memengaruhi perkembangan hama Tribolium sp.

Imago dan larva $T$. castaneum selalu merusak tepung, jika belum terdapat tepung mereka akan menunggu hasil perusakan butir beras, gaplek, jagung, kopra, dan lain-lain oleh hama primer. Ketika terdapat dalam jumlah besar, kumbang tepung akan menyebabkan tepung menjadi rentan terhadap jamur serta dapat mencemari komoditas dengan sekresi dari kelenjar berbau hama tersebut. Serangan berat yang disebabkan oleh $T$. castaneum menyebabkan komoditas tercemar oleh benzokuinon hasil ekskresi kumbang tersebut yang bersifat racun sehingga komoditas tersebut tidak layak untuk dikonsumsi dan menyebabkan tepung berwarna coklat (Hodges et al., 1996; Campbell \& Runnion, 2003). Infestasi $T$ castaneum secara langsung dapat menyebabkan penurunan susut bahan pangan seperti tepung selama penyimpanan (Hodges et al., 1996). Tingkat kerusakan ekonomi pada tepung selama penyimpanan berkisar antara 34-40\% (Ajayi \& Rahman, 2006).

Perbedaan kerentanan terhadap infestasi $T$. castaneum terjadi pada jenis tepung dari pengolahan biji-bijian yang berbeda. Tepung bertipe kasar menyebabkan pertumbuhan populasi yang lebih tinggi hama T. castaneum (Lale \& Yusuf, 2001;
Turaki et al., 2007). Informasi tentang kerentanan jenis tepung terhadap infestasi $T$. castaneum masih terbatas ketersediaannya secara literatur. Kajian tingkat kerentanan jenis tepung sebagai sumber makanan bagi $T$. castaneum digunakan untuk mengidentifikasi jenis tepung yang rentan terhadap T. castaneum selama penyimpanan. Penelitian ini bertujuan untuk mengkaji tingkat kerentanan beberapa jenis tepung terhadap infestasi $T$. castaneum dalam kaitannya dengan pertumbuhan populasi dan median waktu perkembangan $T$. castaneum serta tingkat penyusutan selama masa penyimpanan.

\section{BAHAN DAN METODE}

Penelitian dilakukan di Laboratorium Hama dan Penyakit Tanaman, Fakultas Pertanian, Universitas Malikussaleh. Penelitian dilaksanakan pada bulan Agustus sampai Desember 2015. Serangga dewasa $T$. castaneum diperoleh dari media dedak dengan ukuran bervariasi antara 3-4 mm dengan warna coklat tua. Penelitian dilaksanakan dalam bentuk percobaan laboratorium dengan satu jenis perlakuan yang disusun dalam Rancangan Acak Lengkap (RAL). Jenis perlakuan yang digunakan adalah jenis tepung yang terdiri atas tepung beras, tepung jagung, tepung gandum, tepung tapioka, tepung sagu, tepung kentang, tepung kacang hijau, tepung roti, tepung beras ketan putih, tepung ubi jalar kultivar ungu, dan dedak. Setiap perlakuan diulang sebanyak tiga kali sehingga terdapat 33 satuan percobaan. Data yang diperoleh dari hasil pengamatan dianalisis dengan menggunakan analisis ragam. Untuk membandingkan rata-rata perlakuan dilakukan dengan uji Duncan's Multiple Range Test (DMRT) pada taraf 0,05. Untuk mengukur kekuatan hubungan antara pertumbuhan populasi $T$. castaneum, periode perkembangan, persentase susut berat, dan indeks kerentanan ditentukan dengan analisis korelasi.

\section{Pembiakan dan Infestasi Tribolium castaneum}

Tujuan pembiakan $T$. castaneum adalah untuk memperoleh keturunan dari koloni imago dari $T$. castaneum yang seragam dengan jumlah yang banyak. Pembiakkan serangga $T$. castaneum dilakukan pada stoples pemeliharaan dengan ukuran tinggi $12 \mathrm{~cm}$ dan diameter $15 \mathrm{~cm}$ dengan jenis makanan tepung gandum. Imago $T$. castaneum diinfestasikan ke dalam stoples pemeliharaan dengan tingkat populasi 500 ekor imago T. castaneum secara 
terpisah dengan $250 \mathrm{~g}$ tepung gandum. Stoples pemeliharaan serangga dilengkapi dengan tutup yang dilubangi dan diberi kain kasa untuk aerasi. Stoples-stoples pemeliharaan yang telah berisi imago T. castaneum dan pakan diletakkan pada pada ruangan pemeliharaan di laboratorium. Pembiakan T. castaneum dilakukan dari peletakan telur sampai menjadi pupa. T. castaneum jantan dan betina dipisahkan pada saat stadia pupa (Brown et al., 2009) dari stoples pemeliharaan dan diinfestasikan kembali pada media tepung gandum yang baru sampai menjadi imago.

Pengayakan dilakukan untuk memisahkan imago $T$. castaneum awal dari media tepung gandum. Media tepung gandum tersebut diinkubasikan kembali sampai muncul pupa $T$. castaneum. Imago $T$. castaneum awal tersebut diinfestasi ke dalam stoples pemeliharaan yang berisikan media tepung gandum yang baru untuk pemeliharaan selanjutnya. Imago $T$. castaneum yang digunakan adalah imago yang berumur 7-15 hari karena telah mencapai kedewasaan kawin dan dapat memproduksi telur secara maksimal. Setiap jenis tepung yang digunakan dalam penelitian sebanyak $250 \mathrm{~g}$ dimasukkan ke dalam wadah plastik dengan ukuran tinggi $12 \mathrm{~cm}$ dan diameter $15 \mathrm{~cm}$. Pada tutup stoples plastik diberi lubang aerasi dengan ukuran 4 $\mathrm{cm} \times 4 \mathrm{~cm}$ yang dilapisi kain kasa. Imago $T$. castaneum dari hasil pembiakan diinfestasikan dengan tingkat populasi awal yaitu 10 pasang imago yang ketahui nisbah kelaminnya ke dalam $250 \mathrm{~g}$ beras. Setiap jenis tepung yang telah diinfestasikan dengan imago $T$. castaneum di simpan selama pelaksanaan penelitian.

Pengamatan populasi imago $T$. castaneum diamati sejak 37 sampai 86 hari setelah infestasi $T$. castaneum pada jenis tepung. Pengamatan dilakukan dengan menghitung jumlah imago $T$. castaneum dari setiap perlakuan jenis tepung. Penghitungan populasi imago $T$. castaneum dilakukan pada sampel tepung sebanyak $250 \mathrm{~g}$. Tepung dalam wadah percobaan yang terpisah terlebih dahulu diaduk hingga diperkirakan imago $T$. castaneum terdistribusi secara merata di dalam wadah penelitian. Median waktu perkembangan adalah lama waktu yang diperlukan sejak infestasi $T$. castaneum sampai tercapainya $50 \%$ dari total populasi $T$. castaneum turunan pertama atau setengah dari total turunan pertama (F1) mencapai imago. Informasi periode perkembangan dan jumlah turunan pertama merupakan parameter untuk menentukan kerentanan jenis tepung terhadap $T$. castaneum. Indeks kerentanan (susceptibility index) dihitung menggunakan rumus Dobie (1974) sebagai berikut:

Indeks kerentanan
$=100 \times \frac{\left[\log _{\mathrm{e}}\left(\text { total jumlah progeni } \mathrm{F}_{1} \text { yang muncul }\right)\right]}{\text { Median waktu perkembangan }}$

Tingkat kerentanan jenis tepung terhadap infestasi $T$. castaneum dikelompokkan berdasarkan nilai indeks kerentanan. Katagori kerentanan memiliki rentang nilai yang berkisar antara 0-11 yaitu katagori resisten (indeks kerentanan 0-3), moderat (indeks kerentanan 4-7), rentan (indeks kerentanan 8-10), dan sangat rentan (indeks kerentanan >11) (Dobie, 1974). Penghitungan susut berat tepung dilakukan setelah selesai penelitian. Berat yang hilang selama penelitian dianggap sebagai berat yang susut. Penghitungan susut berat tepung menggunakan rumus sebagai berikut:

Susut berat $=\frac{\text { berat tepung awal }- \text { berat tepung akhir }}{\text { berat tepung awal }} \times 100 \%$

\section{HASIL DAN PEMBAHASAN}

\section{Populasi Imago T. castaneum}

Hasil analisis ragam menunjukkan bahwa jenis tepung berpengaruh sangat nyata terhadap pertumbuhan populasi imago $T$. castaneum (populasi imago 37 HSI: $F=73,62$; populasi imago $44 \mathrm{HSI}: F=$ 101,41; populasi imago $51 \mathrm{HSI}: F=101,20$; populasi imago 58 HSI: $F=157,49$; populasi imago 65 HSI: $F=$ 226,70; populasi imago $72 \mathrm{HSI}: F=300,55$; populasi imago 79 HSI: $F=335,53$; populasi imago 86 HSI: $F=$ 271,81; $P<0,0001)$. Hasil penelitian menunjukkan bahwa jenis-jenis tepung memengaruhi pertumbuhan populasi imago $T$. castaneum. Tepung gandum dan tepung jagung secara nyata dapat meningkatkan populasi imago $T$. castaneum dibandingkan jenis tepung lainnya. Populasi imago $T$. castaneum paling banyak dijumpai pada tepung gandum dan jagung yang berkisar antara 84,751110,25 imago/250 g dan 46,25-1090,50 imago/250 g. Populasi imago $T$. castaneum paling rendah dijumpai pada tepung tapioka dan tepung sagu berkisar antara 20-22 imago/250 g dan 20-22,33 imago/250 g, namun tidak berbeda nyata dengan jenis tepung kentang, tepung panir, tepung ketan putih, dan tepung ubi jalar kultivar ungu. Populasi imago $T$. castaneum pada dedak berkisar antara 37,25-819,75 imago/250 g, sedangkan pada tepung beras dan tepung kacang hijau berkisar antara 25,66- 
756 imago/250 g dan 23,25-221,50 imago/250 g. Tepung gandum dan tepung jagung merupakan jenis makanan yang paling disukai oleh $T$. castaneum dibandingkan dengan tepung tapioka dan tepung sagu (Tabel 1). Urutan tingkat kesesuaian jenis tepung terhadap pertumbuhan populasi yaitu tepung gandum $>$ tepung jagung $>$ dedak $>$ tepung kacang hijau $>$ tepung beras $>$ tepung kentang $>$ tepung ubi jalar kultivar ungu $>$ tepung panir $>$ tepung ketan putih $>$ tepung tapioka $=$ tepung sagu .

Tabel 1. Pengaruh jenis tepung terhadap pertumbuhan populasi imago T. castaneum.

\begin{tabular}{lllllllll}
\hline \multirow{2}{*}{ Jenis tepung } & \multicolumn{7}{c}{ Populasi T. castaneum (imago/250 g) } \\
\cline { 2 - 8 } & \multicolumn{1}{c}{$37 \mathrm{HSI}$} & $44 \mathrm{HSI}$ & $51 \mathrm{HSI}$ & $58 \mathrm{HSI}$ & $65 \mathrm{HSI}$ & $72 \mathrm{HSI}$ & $79 \mathrm{HSI}$ & \multicolumn{1}{c}{$86 \mathrm{HSI}$} \\
\hline Tepung beras & $90,50 \mathrm{~d}$ & $142,67 \mathrm{~d}$ & $162,83 \mathrm{c}$ & $182,33 \mathrm{~d}$ & $188,83 \mathrm{e}$ & $195,33 \mathrm{e}$ & $205,83 \mathrm{e}$ & $216,33 \mathrm{~d}$ \\
Tepung gandum & $352,17 \mathrm{a}$ & $653,67 \mathrm{a}$ & $699,50 \mathrm{a}$ & $864,33 \mathrm{a}$ & $967,83 \mathrm{a}$ & $1038,67 \mathrm{a}$ & $1076,33 \mathrm{a}$ & $1118,67 \mathrm{a}$ \\
Tepung jagung & $166,83 \mathrm{c}$ & $291,67 \mathrm{c}$ & $534,50 \mathrm{~b}$ & $772,67 \mathrm{~b}$ & $822,17 \mathrm{~b}$ & $938,33 \mathrm{~b}$ & $973,83 \mathrm{~b}$ & $1038,33 \mathrm{a}$ \\
Tepung tapioka & $20 \mathrm{e}$ & $20 \mathrm{e}$ & $20 \mathrm{~d}$ & $20 \mathrm{e}$ & $20 \mathrm{f}$ & $21 \mathrm{f}$ & $21,33 \mathrm{f}$ & $22 \mathrm{e}$ \\
Tepung sagu & $20 \mathrm{e}$ & $20 \mathrm{e}$ & $20 \mathrm{~d}$ & $21 \mathrm{e}$ & $22,33 \mathrm{f}$ & $22,33 \mathrm{f}$ & $22,67 \mathrm{f}$ & $22,33 \mathrm{e}$ \\
Tepung kentang & $20 \mathrm{e}$ & $20 \mathrm{e}$ & $26,67 \mathrm{~d}$ & $30 \mathrm{e}$ & 30,67 & $33 \mathrm{f}$ & $39,33 \mathrm{f}$ & $56,33 \mathrm{e}$ \\
Tepung kacang hijau & $25,67 \mathrm{e}$ & $31 \mathrm{e}$ & $57,33 \mathrm{~d}$ & $179,33 \mathrm{~d}$ & $316,33 \mathrm{~d}$ & $422,67 \mathrm{~d}$ & $542,33 \mathrm{~d}$ & $756,33 \mathrm{c}$ \\
Tepung panir & $21,33 \mathrm{e}$ & $21,33 \mathrm{e}$ & $22 \mathrm{~d}$ & $29,33 \mathrm{e}$ & $31,67 \mathrm{f}$ & $33,33 \mathrm{f}$ & $36 \mathrm{f}$ & $44,67 \mathrm{e}$ \\
Tepung ketan putih & $21,33 \mathrm{e}$ & $21,33 \mathrm{e}$ & $21,33 \mathrm{~d}$ & $21 \mathrm{e}$ & $22 \mathrm{f}$ & $25 \mathrm{f}$ & $31 \mathrm{f}$ & $32,67 \mathrm{e}$ \\
Tepung ubi jalar & $20,67 \mathrm{e}$ & $20,67 \mathrm{e}$ & $20,67 \mathrm{~d}$ & $26 \mathrm{e}$ & $29 \mathrm{f}$ & $32,67 \mathrm{f}$ & $39,33 \mathrm{f}$ & $49,33 \mathrm{e}$ \\
Dedak & $263,83 \mathrm{~b}$ & $470,67 \mathrm{~b}$ & $552,67 \mathrm{~b}$ & $614,67 \mathrm{c}$ & $645,33 \mathrm{c}$ & $675,33 \mathrm{c}$ & $765,67 \mathrm{c}$ & $852,67 \mathrm{~b}$ \\
\hline
\end{tabular}

Keterangan: Angka yang diikuti oleh huruf yang sama pada kolom yang sama tidak berbeda nyata berdasarkan uji DMRT pada taraf 0,05 .

Perbedaan jenis tepung dapat memengaruhi pertumbuhan dan laju pertumbuhan populasi serangga hama pascapanen seperti $T$. castaneum. Seperti yang dikemukan oleh Inouye \& Lerner (1965) bahwa perbedaan jenis makanan dapat memengaruhi pertumbuhan populasi serangga hama pascapanen. Pertumbuhan populasi $T$. castaneum dipengaruhi oleh kandungan nutrisi dari jenis tepung. Campbell \& Runnion (2003) menyatakan bahwa perbedaan jenis tepung mengindikasikan perbedaan kandungan nutrisi yang dapat memengaruhi perkembangan dan pertumbuhan populasi T. castaneum. Sokoloff et al. (1966) mengemukakan bahwa $T$. castaneum dapat merusak berbagai jenis tepung, namun $T$. castaneum sangat peka terhadap kandungan nutrisi dari makanannya. Kualitas makanan memiliki pengaruh langsung terhadap tingkat perkembangan $T$. castaneum (Desharnais, 1997). Kandungan nutrisi pada jenis tepung memiliki peranan dalam peningkatan pertumbuhan populasi T. castaneum. Pertumbuhan populasi $T$. castaneum sangat tergantung pada kualitas nutrisi. Serangga membutuhkan nutrisi dalam bentuk karbohidrat, protein, lemak, sterol, vitamin, asam nukleat, air, dan mineral (Chapman, 1998; Nation, 2002). Nutrisi yang dibutuhkan oleh serangga harus dalam proporsi berimbang, jika serangga tidak mendapat kebutuhan nutrisi yang berimbang, maka serangga akan mengalami kegagalan ganti kulit, tidak meletakan telur, tidak bercahaya (seperti pada kumbang), dan mengalami perubahan pada warna tubuh serangga (Chapman, 1998).

Kandungan nutrisi pada tepung gandum dan tepung jagung lebih tinggi sehingga $T$. castaneum memiliki preferensi yang tinggi terhadap kedua jenis tepung tersebut dibandingkan dengan tepung beras dan dedak. Hasil penelitian Wong \& Lee (2011) menunjukkan bahwa pertumbuhan populasi $T$. castaneum mengalami peningkatan pada substrat yang mengandung protein tinggi. Protein merupakan unsur essensial yang dibutuhkan oleh imago serangga betina untuk produksi telur (Chapman, 1998). Kandungan protein pada tepung gandum lebih tinggi dibandingkan dengan tepung jagung, tepung beras, dan dedak sehingga $T$. castaneum sangat menyukai tepung gandum. Kadar protein pada tepung gandum adalah 14,9\% (Widaningrum dkk., 2005), tepung jagung berkisar antara 7,45-7,89\% (Richana \& Suarni, 2007), tepung beras yaitu $6,98 \%$ (Imanninggsih, 2012), tepung tapioka yaitu $1,10 \%$ (Soemarno, 2007), tepung sagu yaitu $0,70 \%$ (Rahim dkk., 2009), tepung ubi jalar kultivar ungu yaitu 1,69\% (Winarno, 1994), dedak berkisar antara 9,76-12,55\% (Akbarillah dkk., 2007; Hadipernata dkk., 2012), tepung kentang yaitu 0,6\%, serta tepung kacang hijau yaitu 19,09\% (Ratnasari \& Yunianta, 2015). Karbohidrat merupakan polimer polisakarida yang dibutuhkan serangga untuk berbagai kepentingan, misalnya sebagai sumber 
energi dan pertumbuhan populasi. Secara umum karbohidrat yang diserap oleh serangga dalam bentuk monosakarida bukan dalam bentuk disakarida ataupun polisakarida di dalam sistem pencernaan makanan (Chapman, 1998). Kadar karbohidrat dari tepung gandum yaitu 69,9\% (Widaningrum dkk., 2005), tepung jagung berkisar antara 75,12-85,27\% (Suarni dkk., 2013), tepung beras yaitu 80,3\% (Imanninggsih, 2012), dedak berkisar antara 52-53,29\% (Hadipernata et al., 2012), tepung kacang hijau yaitu 63,55\% (Shah et al., 2011), tepung ubi jalar kultivar ungu yaitu $86,37 \%$ (Winarno,1994), tepung kentang yaitu $81,91 \%$, tepung panir yaitu 19,9\%, tepung sagu yaitu $84,7 \%$ (Rahim dkk., 2009), dan tepung tapioka yaitu $78,13 \%$. Serangga-serangga di penyimpanan seperti spesies Tribolium, Lasioderma dan Ptinus dapat mencapai pertumbuhan sampai dewasa pada kondisi kekurangan karbohidrat dalam makanannya (Nation, 2002).

\section{Median Waktu Perkembangan T. castaneum}

Hasil analisis ragam menunjukkan bahwa jenis tepung berpengaruh sangat nyata terhadap median waktu perkembangan hama $T$. castaneum ( $F$ =69,03; $\mathrm{db}=10 ; P<0,0001)$. Tepung gandum, jagung, dan beras secara nyata menyebabkan median waktu perkembangan $T$. castaneum lebih rendah dibandingkan jenis tepung lainnya. Median waktu perkembangan $T$. castaneum paling cepat dijumpai pada tepung gandum yaitu 23,25 hari yang tidak berbeda nyata dengan tepung jagung dan tepung beras yaitu 24,75 dan 28,67 hari. Median waktu perkembangan $T$. castaneum paling lama dijumpai pada tepung tapioka dan tepung sagu yaitu 86 hari dan tidak berbeda nyata dengan tepung ketan putih. Median waktu perkembangan $T$. castaneum tepung kentang yaitu 57,33 hari dan tidak berbeda nyata dengan tepung panir dan tepung ubi jalar kultivar ungu. Median waktu perkembangan $T$. castaneum dedak yaitu 32,33 hari dan tidak berbeda nyata dibandingkan dengan tepung kacang hijau (Tabel 2).

Tabel 2. Pengaruh jenis tepung terhadap median waktu perkembangan $T$. castaneum, persentase susut berat tepung, dan indeks kerentanan.

\begin{tabular}{lccll}
\hline \multicolumn{1}{c}{ Jenis tepung } & $\begin{array}{c}\text { Median waktu } \\
\text { perkembangan } \\
\text { (hari) }\end{array}$ & $\begin{array}{c}\text { Persentase susut } \\
\text { berat }\end{array}$ & $\begin{array}{c}\text { Indeks } \\
\text { kerentanan }\end{array}$ & Katagori kerentanan \\
\hline Tepung beras & $28,67 \mathrm{~d}$ & $14,56 \mathrm{c}$ & $8,11 \mathrm{~d}$ & Rentan \\
Tepung gandum & $23,33 \mathrm{~d}$ & $22,32 \mathrm{a}$ & $13,07 \mathrm{a}$ & Sangat rentan \\
Tepung jagung & $27,33 \mathrm{~d}$ & $21,28 \mathrm{a}$ & $11,08 \mathrm{~b}$ & Sangat rentan \\
Tepung tapioka & $86 \mathrm{a}$ & $3,12 \mathrm{f}$ & $1,56 \mathrm{~h}$ & Resisten \\
Tepung sagu & $86 \mathrm{a}$ & $3,34 \mathrm{f}$ & $1,57 \mathrm{~h}$ & Resisten \\
Tepung kentang & $57,33 \mathrm{~b}$ & $11,81 \mathrm{~d}$ & $3,12 \mathrm{f}$ & Resisten-moderat \\
Tepung kacang hijau & $45,33 \mathrm{c}$ & $17,67 \mathrm{~b}$ & $6,36 \mathrm{e}$ & Moderat \\
Tepung panir & $62,33 \mathrm{~b}$ & $10,68 \mathrm{ed}$ & $2,66 \mathrm{fg}$ & Resisten \\
Tepung ketan putih & $78,67 \mathrm{a}$ & $8,13 \mathrm{e}$ & $1,93 \mathrm{gh}$ & Resisten \\
Tepung ubi jalar & $65,67 \mathrm{~b}$ & $10,86 \mathrm{~d}$ & $2,59 \mathrm{fg}$ & Resisten \\
Dedak & $32,33 \mathrm{c}$ & $18,08 \mathrm{~b}$ & $9,06 \mathrm{c}$ & Rentan \\
\hline
\end{tabular}

Keterangan: Angka yang diikuti oleh huruf yang sama pada kolom yang sama tidak berbeda nyata berdasarkan uji DMRT pada taraf 0,05 .

Median waktu perkembangan merupakan parameter yang biasa digunakan untuk mengukur tingkat keefektifan bahan pangan terhadap perkembangan serangga, semakin tinggi nilai median waktu perkembangan serangga, maka semakin resisten jenis tepung tersebut terhadap infestasi serangga $T$. castaneum. Nilai median waktu perkembangan yang semakin rendah menunjukkan periode perkembangan atau siklus hidup yang semakin cepat pada $T$. castaneum. Berdasarkan parameter median waktu perkembangan $T$. castaneum diketahui bahwa jenis tepung gandum, tepung jagung, dan tepung beras menyebabkan waktu perkembangan dari telur sampai menjadi imago lebih cepat dibandingkan dengan jenis tepung lainnya, sedangkan periode perkembangan paling lama pada tepung tapioka dan tepung sagu. Sesuai dengan hasil penelitian Ajayi \& Rahman (2006) yang menunjukkan bahwa waktu perkembangan $T$. castaneum paling cepat dijumpai pada tepung gandum dan paling lama terjadi pada tepung tapioka. Waktu perkembangan berkisar antara 27-54,8 hari. 
Perbedaan median waktu perkembangan $T$. castaneum pada jenis tepung menunjukkan perbedaan tingkat kerentanan terhadap serangan $T$. castaneum. Periode perkembangan paling cepat perkembangan yang tinggi pada tepung gandum dan tepung jagung menunjukkan kedua jenis tepung memliki tingkat kerentanan lebih tinggi dibandingkan tepung lainnya.

\section{Persentase Susut Berat}

Hasil analisis ragam menunjukkan bahwa jenis tepung berpengaruh sangat nyata terhadap persentase susut berat tepung $(F=55,56 ; \mathrm{db}=10 ; P<$ 0,0001). Hasil penelitian menunjukkan bahwa jenis tepung memengaruhi persentase susut berat akibat aktivitas makan dari $T$. castaneum. Tepung gandum dan tepung jagung secara nyata menyebabkan persentase susut berat lebih tinggi dibandingkan tepung lainnya. Persentase susut berat paling tinggi dijumpai pada tepung gandum dan tepung jagung yaitu $22,32 \%$ dan $21,28 \%$, sedangkan persentase susut berat paling rendah dijumpai pada tepung tapioka dan tepung sagu yaitu 3,12\% dan 3,34\%. Persentase susut berat pada tepung kacang hijau mencapai $17,67 \%$ dan berbeda nyata dibandingkan dengan dedak. Aktivitas makan T. castaneum pada tepung panir, tepung kentang dan tepung ubi jalar kultivar ungu menyebabkan persentase susut berat yang tidak berbeda nyata. Persentase susut berat pada tepung ketan putih mencapai 8,13\% (Tabel 2). Hama $T$. castaneum sangat menyukai tepung gandum dan tepung jagung sebagai sumber makanan dibandingkan dengan jenis tepung lainnya sehingga persentase susut berat lebih tinggi pada kedua jenis tepung tersebut. Hasil penelitian Kheradpir (2014) menunjukkan bahwa $T$. castaneum memiliki preferensi yang tinggi terhadap tepung gandum dibandingkan tepung beras serta kurang menyukai tepung kentang. Sesuai dengan hasil penelitian Ajayi \& Rahman (2006) yang menunjukkan bahwa kehilangan hasil secara ekonomi terjadi pada tepung gandum yang disebabkan oleh hama pascapanen $T$. castaneum. Aktivitas makan yang dilakukan oleh $T$. castaneum menyebabkan bahan pangan di penyimpanan mengalami kehilangan berat. Di antara jenis makanan yang diuji, tepung gandum dan tepung jagung yang paling disukai oleh $T$. castaneum. Hama $T$. castaneum tidak memiliki kemampuan untuk merusak produk bahan pangan yang masih utuh tetapi mampu berkembangbiak dengan cepat pada bahan pangan yang mengalami pengolahan lanjutan menjadi tepung atau atau telah dirusak oleh hama primer lainnya (Kayode et al., 2014).

\section{Indeks Kerentanan}

Pengukuran indeks kerentanan pada beberapa jenis tepung terhadap serangan $T$. castaneum dilakukan dengan menghitung nilai indeks kerentanan menggunakan nilai Indeks Kerentanan Dobie (IKD). Nilai indeks kerentanan menggambarkan tingkat kerentanan jenis-jenis tepung sehingga semakin tinggi nilai indeks kerentanan maka tepung tersebut semakin rentan sedangkan jika nilai indeks kerentanan semakin rendah maka tepung tersebut semakin resisten terhadap serangan $T$. castaneum. Hasil analisis ragam menunjukkan bahwa jenis tepung berpengaruh sangat nyata terhadap indeks kerentanan tepung dari infestasi $T$. castaneum ( $F=$ 259,51; $\mathrm{db}=10 ; P<0,0001)$. Nilai indeks kerentanan dari jenis tepung terhadap infestasi hama $T$. castaneum berkisar antara 1,56-13,07. Nilai indeks kerentanan paling rendah dijumpai pada tepung tapioka dan tepung sagu yaitu 1,56 dan 1,57, namun tidak berbeda nyata dengan tepung ketan putih. Nilai indeks kerentanan paling tinggi dijumpai pada tepung gandum yaitu 13,07. Nilai indeks kerentanan pada tepung beras dan tepung jagung mencapai 11,08 dan 8,11, sedangkan pada dedak mencapai 9,06. Nilai indeks kerentanan pada kacang hijau mencapai 6,36. Nilai indeks kerentanan pada tepung ubi jalar kultivar ungu dan tepung panir sebesar 2,59 dan 2,66 yang tidak berbeda nyata dibandingkan dengan tepung kentang (Tabel 2).

Indeks kerentanan Dobie merupakan pengklasifikasian tingkat kerentanan varietas terhadap hama gudang yang sudah umum digunakan, yaitu kerentanan ditentukan oleh periode perkembangan dan populasi serangga hama pascapanen. Berdasarkan hasil klasifikasi skor kriteria kerentanan diketahui bahwa tepung tapioka, tepung sagu, tepung ketan putih, tepung ubi jalar kultivar ungu, dan tepung panir tergolong katagori resisten terhadap serangan hama $T$. castaneum. Tepung kentang tergolong katagori resisten sampai moderat, sedangkan tepung kacang hijau tergolong katagori moderat. Tepung beras dan dedak tergolong katagori rentan, sedangkan tepung jagung dan gandum tergolong katagori sangat rentan terhadap serangan hama $T$. castaneum selama di penyimpanan (Tabel 2). Hasil penelitian Ajayi \& Rahman (2006) menunjukkan bahwa tepung tapioka tergolong resisten dan tepung gandum tergolong rentan 
terhadap $T$. castaneum selama di penyimpanan. Kayode et al. (2014) juga mengemukakan bahwa tepung gandum tergolong rentan dan tepung jagung tergolong sangat rentan terhadap $T$. castaneum. Kerentanan jenis tepung terhadap $T$. castaneum berkaitan dengan kandungan nutrisi dari tepung seperti protein dan karbohidrat. Jenis tepung yang rentan terhadap $T$. castaneum berkaitan dengan tingginya kandungan protein dan rendahnya kandungan karbohidrat. Wong \& Lee (2011) menyatakan bahwa jumlah kemunculan imago $T$. castaneum meningkat pada tepung dengan kandungan protein tinggi dan menurun pada tepung yang memiliki kandungan karbohidrat tinggi.

Hasil analisis korelasi menunjukkan bahwa terdapat korelasi positif yang sangat nyata antara indeks kerentanan dengan populasi imago $T$. castaneum dan persentase susut berat serta terdapat korelasi negatif yang sangat nyata dengan periode perkembangan $T$. castaneum (Tabel 3). Korelasi antar karakter ini menunjukkan bahwa peningkatan nilai indeks kerentanan dari jenis tepung dipengaruhi oleh peningkatan populasi imago $T$. castaneum $\left(r=0,951^{* *} ; P<0,01\right)$ dan persentase susut berat $\left(r=0,922^{* *} ; P<0,01\right)$ serta median waktu perkembangan $T$. castaneum yang cepat $\left(r=-0,939^{* *}\right.$; $P<0,01$ ) (Tabel 3). Peningkatan populasi $T$. castaneum dan persentase susut berat menyebabkan peningkatan nilai indeks kerentanan, serta median waktu perkembangan $T$. castaneum yang lama menyebabkan penurunan nilai indeks kerentanan, sehingga jenis tepung menjadi resisten sampai sangat rentan. Preferensi hama pascapanen seperti $T$. castaneum terhadap tepung sebagai sumber makanan dan oviposisi bervariasi menurut jenis tepung. Pengetahuan tentang perilaku T. castaneum dan karakteristik jenis tepung dapat membantu mendeteksi kerusakan dan kerugian tepung yang disebabkan oleh $T$. castaneum selama penyimpanan.

Tabel 3. Matriks korelasi antara populasi imago, periode perkembangan $T$. castaneum dan persentase susut berat tepung terhadap indeks kerentanan dari jenis tepung.

\begin{tabular}{lcccc}
\hline \multicolumn{1}{c}{ Karakter } & $\begin{array}{c}\text { Populasi imago } \\
\text { T. castaneum }\end{array}$ & $\begin{array}{c}\text { Periode } \\
\text { perkembangan }\end{array}$ & $\begin{array}{c}\text { Persentase } \\
\text { susut berat }\end{array}$ & $\begin{array}{c}\text { Indeks } \\
\text { kerentanan }\end{array}$ \\
\hline Populasi imago T. castaneum & 1 & & & \\
Periode perkembangan & $-0,820^{* *}$ & 1 & 1 & \\
Persentase susut berat & $0,869^{* *}$ & $-0,950^{* *}$ & $0,922^{* *}$ & 1 \\
Indeks kerentanan & $0,951^{* *}$ & $-0,939^{* *}$ & \\
\hline
\end{tabular}

Keterangan: ${ }^{*}$ berkorelasi sangat nyata $(\mathrm{p}<0,01) ;{ }^{*}$ berkorelasi nyata $(\mathrm{p}<0,05)$

\section{SIMPULAN}

Tingkat kerentanan jenis tepung terhadap serangan hama $T$. castaneum yaitu tepung tapioka, tepung sagu, tepung ketan putih, tepung ubi jalar kultivar ungu dan tepung panir tergolong resisten. Tepung kentang tergolong resisten sampai moderat, sedangkan tepung kacang hijau tergolong moderat. Tepung beras dan dedak tergolong rentan, sedangkan tepung jagung dan gandum tergolong sangat rentan. Pertumbuhan populasi paling tinggi terdapat pada tepung gandum, tepung jagung, dedak dan tepung kacang hijau sehingga menyebabkan peningkatan persentase susut berat pada tepung tersebut. Periode perkembangan $T$. castaneum paling lama terjadi pada tepung sagu dan tapioka dan paling cepat pada tepung gandum.

\section{DAFTAR PUSTAKA}

Ajayi, FA and SA Rahman. 2006. Susceptibility of some staple processed meals to red flour beetle, Tribolium castaneum (Herbst) (Coleoptera: Tenebrionidae). Pakistan Journal of Biological Sciences. 9:1744-1748.

Akbarillah, T Hidayat, dan T Khoiriyah. 2007. Kualitas dedak dari berbagai varietas padi di Bengkulu Utara. Jurnal Sain Peternakan Indonesia 2(1): 36-41.

Brown, SJ, TD Shippy, S Miller, R Bolognesi, RW Beeman, MD Lorenzen, G Bucher, EA Wimmer, and M Klingler. 2009. The red flour beetle, Tribolium castaneum(Coleoptera): A model for studies of development and pest biology. Cold Spring Harbor Protoc. 126: 1-8. 
Campbell, JF and C Runnion. 2003. Patch exploitation by female red flour beetles, Tribolium castaneum. Journal of Insect Science. 3:1-8.

Chapman, RF. 1998. The Insect Structure and Function. Harvard University Press. Cambridge.

Desharnais, RA. 1997. Population dynamics of Tribolium. Pp. 302-328 in Structured Population Models in Marine, Terrestrial, and Freshwater Systems. (S Tuljapurkar and H Caswell, eds.). Chapman \& Hall. New York.

Dobie, P. 1974. The laboratory assessment of the inherent susceptibility of maize varieties to post harvest infestation by Sitophilus zeamais Motsch. (Coleoptera: Curculionidea) infesting field corn. Journal of Entomology Science. 21:367-375.

Hadipernata, M, W Supartono, dan MAF Falah. 2012. Proses stabilisasi dedak padi (Oryza sativa L) menggunakan radiasi far infra red (fir) sebagai bahan baku minyak pangan. Jurnal Aplikasi Teknologi Pangan. 1(4):103107.

Hodges, RJ, R Robinson, and DR Hall. 1996. Quinone contamination of dehusked rice by Tribolium castaneum (Herbs) (Coleoptera: Tenebrionidae). Journal of Stored Product Research. 32:31-37.

Inouye, $\mathrm{N}$ and IM Lerner. 1965. Competition between Tribolium species (Coleoptera: Tenebrionidae) on several diets. Journal of Stored Product Research. 1:185-191.

Kayode, OY, CO Adedire, and RO Akinkurolere. 2014. Influence of four cereal flours on the growth of Tribolium castaneum Herbst (Coleoptera: Tenebrionidae). Ife Journal of Science. 16(3):505-516.

Kheradpir, N. 2014. Food preference of T. castaneum among four flour types. European Journal of Experimental Biology. 4(1):436-439.

Lale, NES and BA Yusuf. 2001. Potential of varietal resistance and Piper guineense seed oil to control infestation of stored millet seeds and processed products by Tribolium castaneum (Herbst). Journal of Stored Product Research. 37:63-75.

Mewis, I and CH Ulrichs. 2001. Action of amorphous diatomaceous earth against different stages of the stored product pests Tribolium confusum, Tenebrio molitor,
Sitophilus granarium and Plodia interpunctella. Journal of Stored Product Research. 37:153-164.

Nation, JL. 2002. Insect Physiology and Biochemistry. CRC Press. London.

Odeyemi, OO, BM Oyedare, and MO Ashamo. 2005. Resistance of seven biscuit types to infestation by Tribolium castaneum (Herbst) (Coleoptera: Tenebrionidae). Zoological Research. 26(3):300-304.

Rahim, A, Mappiratu, dan N Amalia. 2009. Sifat fisikokimia dan sensoris sohun instan dari pati sagu. Jurnal Agroland. 6(2):124-129.

Ratnasari, D dan Yunianta. 2015. Pengaruh tepung kacang hijau, tepung labu kuning, margarin terhadap fisikokima dan organoleptik biskuit. Jurnal Pangan dan Agroindustri 3(4): 1652-1661.

Richana, N dan Suarni. 2007. Teknologi pengolahan jagung. Hlm. 386-409 dalam Jagung: Teknik Produksi dan Pengembangan (Sumarno, Suyamto, A Widjono, Hermanto, dan $\mathrm{H}$ Kasim, ed.). Pusat Penelitian dan Pengembangan Tanaman Pangan. Departemen Pertanian.

Sarwar, M. 2015. Categorization of some advanced local wheat lines Tribolium against castaneum (Herbst) (Coleoptera: Tenebrionidae). International Journal of Life Science and Engineering. 1(3):108-113.

Shah, SA, A Zeb, T Masood, N Noreen, SJ Abbas, M Samiullah, MdA Alim, and A Muhammad. 2011. Effect of sprouting time on biochemical and nutritional qualities of mungbean varieties. Journal of Agricultural Research. 6(22):5091-5098.

Soemarno. 2007. Rancangan Teknologi Proses Pengolahan Tapioka dan Produkproduknya. Universitas Brawijaya Malang. Malang.

Suarni, IU Firmansyah, dan M Aqil. 2013. Keragaman mutu pati beberapa varietas jagung. Penelitian Pertanian Tanaman Pangan. 32(1):50-56.

Turaki, JM, BM Sastawa, BGJ Kabir, and NES Lale. 2007. Susceptibility of flours derived from various cereal grains to infestation by the rust-red flour beetle (Tribolium castaneum Herbst) (Coleoptera: Tenebrionidae) in different seasons. Journal of Plant Protection Research. 47(3):279-288. 
Verheggen, F, C Ryne, POC Olsson, L Arnaud, G Lognay, HE Högberg, D Persson, E Haubruge, and C Löfsted. 2007. Electrophysiological and behavioral activity of secondary metabolites in the confused flour beetle, Tribolium confusum. Journal of Chemical Ecology. 33(3):525-539.

Weston, PA and PL Rattlingourd. 2000. Progeny production by Tribolium castaneum (Coleoptera: Tenebrionidae) and Oryzaephilus surinamensis (Coleopetera: Silvanidae) on maize previously infested by Sitotroga cerealla (Lepidoptera: Gelechiidae). Journal of Economic Entomology. 93:533-536.
Widaningrum, S Widowati, dan ST Soekarto. 2005. Pengayaan tepung kedelai pada pembuatan mie basah dengan bahan baku tepung terigu yang disubstitusi tepung garut. Jurnal Pascapanen. 2(1):4-48.

Winarno, FG. 1994. Kimia Pangan dan Gizi. PT Gramedia Pustaka Utama. Jakarta.

Wong, N and CY Lee. 2011. Relationship between population growth of the red flour beetle Tribolium castaneum and protein and carbohydrate content in flour and starch. Journal of Economic Entomology. 104(6):2087-2094. 